\title{
ISOLATION AND STRUCTURE OF ASCOFURANONE AND ASCOFRANOL, ANTIBIOTICS WITH HYPOLIPIDEMIC ACTIVITY
}

\author{
Hiroshi Sasakr, Tomoyoshi Hosokawa, Mikio Sawada \\ and KunIo ANDO \\ Research Laboratories, Chugai Pharmaceutical Co., Ltd., \\ Takada, Toshima-ku, Tokyo, Japan
}

(Received for publication August 3, 1973)

\begin{abstract}
A new antibiotic with hypolipidemic activity, ascofuranone, $\mathrm{C}_{23} \mathrm{H}_{29} \mathrm{ClO}_{5}$, and related substance, ascofuranol, $\mathrm{C}_{23} \mathrm{H}_{31} \mathrm{ClO}_{5}$, were isolated from the filter cake of the fermented broth of Ascochyta viciae LIBERT, an ascochlorin-producing fungus, and their structures were elucidated. They possess 3-substituted-5-chloro-orcylaldehyde moiety with novel sesquiterpenyl side chains.
\end{abstract}

In our screening for hypolipidemic agents from microorganisms, new prenylphenols ${ }^{11}$, ascofuranone ${ }^{21}$ (I) and ascofuranol (II), were isolated from an ascochlorin-producing fungus, Ascochyta viciae LIBERT $^{3,4}$. In this paper the isolation and structure of these novel prenylphenols are described.

Mutants of $A$. viciae were isolated by nitrosoguanidine treatment to improve ascochlorin yield. Two new prenylphenols were found in the mycelial acetone extract of a mutant No. 34, when the extract was subjected to silica gel thin-layer chromatography using $n$-hexane - acetone (4:1) as a developing solvent. The mutant was grown in 30-liter jar fermentor containing the medium previously reported $^{3)}$. After one week of submerged fermentation, the mycelium was collected by filtration and extracted with a mixture of chloroform - methanol $(9: 1)$. The chloroform extract was evaporated in vacuo and the residue soaked in $n$-hexane. Ascochlorin (III) crystallized slowly in a refrigerator and was removed by filtration. The mother liquor was again evaporated and the residue chromatographed on a column of silica gel. Elution with $n$ -

Fig. 1. Structures of ascofuranone and related substances.<smiles>[R]C1C[C@H](/C(C)=C/C/C=C(C)/C=C/[CH]c2c(O)c(Cl)c(C)c(C=O)c2O)OC1(C)C</smiles><smiles>CC(C=CC1(C)C(C)CCC(=O)C1C)=CCc1c(O)c(Cl)c([N+](=O)[O-])c(C=O)c1O</smiles>

Ascochlorin (III)<smiles>CCCCCCC1C(C)CCC(=O)C1C</smiles>

$L L-Z 1272 \&$ (IV)

hexane - acetone (95: 5) yielded ascofuranone (I), $\mathrm{C}_{23} \mathrm{H}_{29} \mathrm{ClO}_{5}, \mathrm{mp} 84 \sim 85^{\circ} \mathrm{C},[\alpha]_{\mathrm{D}}^{11}-50^{\circ}$ (c 1, methanol); further elution with $n$-hexane - acetone (4:1) yielded ascofuranol (II), $\mathrm{C}_{23} \mathrm{H}_{31} \mathrm{ClO}_{5}, \mathrm{mp} 75^{\circ} \mathrm{C}$, $[\alpha]_{\mathbb{D}}^{21}-7^{\circ}(c 1$, methanol), Rf values on Merck silica gel G plate, 0.42 for $\mathbf{I}, 0.23$ for $\mathbf{I I}$ and 0.35 for III.

I and II are colorless needles from $n$-hexane - acetone $(4: 1)$ and showed positive BEILSTEIN and ferric chloride tests. The presence of two olefinic bonds was evident from consumption of two moles of bromine per mole, and a tetrahydro-derivative was formed by catalytic hydrogenation. 
Table 1. UV absorption maxima

\begin{tabular}{l|c|c|c|c}
\hline \multirow{2}{*}{} & \multicolumn{3}{|c|}{$\max$ (molar absorptivity) } & $\begin{array}{c}\text { Shift of principal } \\
\text { ET band at } \\
\text { alkaline condi- } \\
\text { tion (nm) }\end{array}$ \\
\hline Ascochlorin & $\begin{array}{c}\text { LE band } \\
(\mathrm{nm})\end{array}$ & $\begin{array}{c}\text { ET band I } \\
(\mathrm{nm})\end{array}$ & $\begin{array}{c}\text { ET band II } \\
(\mathrm{nm})\end{array}$ & 56 \\
Ascofuranone & $250(29,600)$ & $290(10,600)$ & $350(11,000)$ & 57 \\
Ascofuranol & $228(20,300)$ & $290(15,000)$ & $350(8,200)$ & 57 \\
LL-Z1272 & $228(15,800)$ & $290(8,700)$ & $352(13,900)$ & 56 \\
\hline
\end{tabular}

Fig. 2. IR spectra of ascofuranone (A) and ascofuranol (B)

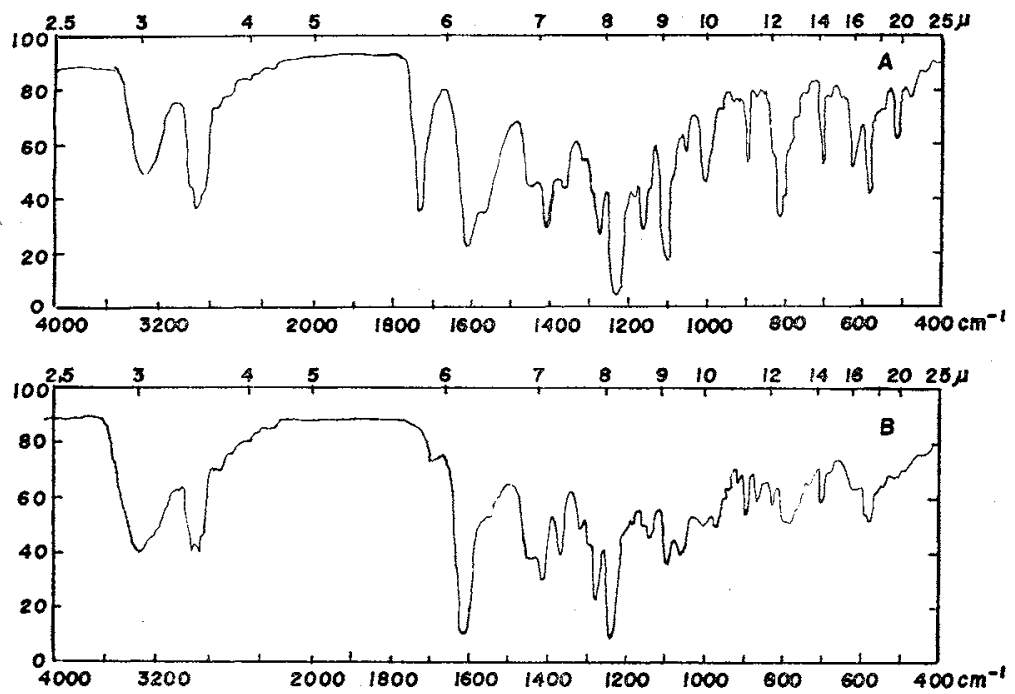

The UV absorption spectra of I and II (Table 1) were strongly reminiscent of the 3- substituted5-chloroorcylaldehyde system ${ }^{53}$ as were the mass (Figs. 3, 4), NMR (Table 2), and IR (Fig. 2) spectral properties. The three absorption maxima with high molar absorptivity are characteristic for a phenol with a chelated carbonyl such as $o$-hydroxyacetophenone and III (Table 1). The principal ET bands of I, II and III are nearly the same, indicating that I and II posesses the same chromophore as III. This was further supported by the bathochromic shift, $57 \mathrm{~nm}$, at basic condition. The UV spectra of I and II are practically indistinguishable from that of an ascochlorin analog, LL-Z1272 $\delta\left(\right.$ IV) ${ }^{6}$. This fact means that $I$ and II differentiate from III in unconjugated side chains like $I^{5}{ }^{5}$. The partial structure is corroborated for the following reasons: (A) a common base peak, $m / e 199$, which is a tropilium ion $^{7)}$ derived from side chain fission between $\mathrm{C}-1^{\prime}$ and $\mathrm{C}-2^{\prime}$, appears in all mass spectra (MS); (B) lack of the IR absorption band at $965 \mathrm{~cm}^{-1}$ which is assignable to a transconjugated diene in III; (C) the methylene attached at $\mathrm{C}-3$ appears $0.13 \mathrm{ppm}$ higher than that of III; (D) the signal of the methyl attached at $\delta 2.56$, indicating that the methyl is shifted to low field by an adjacent chlorine; (E) a strong carbonyl absorption around $1630 \mathrm{~cm}^{-1}$ is in accord with 2,4-dihydroxybenzaldehyde system ${ }^{8)}$.

An isoprenoidal origin of the side chain was suggested by the composition, $\mathrm{C}_{15} \mathrm{H}_{23} \mathrm{O}_{2}$, and the four methyls at $\delta 1.20,1.26,1.63$ and 1.79 of $\mathbf{I}$; the former two are aliphatic geminal dimethyls and the latter two those attached to olefinic bonds. On irradiation of a doublet at $\delta 3.38$ (a methylene attached at $\mathrm{C}-3$ ), a triplet at $\delta 5.21$ (an olefinic proton at $\mathrm{C}-2^{\prime}$ ) collapsed into a singlet. This isolated 
coupling system allowed us to assign them as aromatic ring $-\mathrm{CH}_{2}-\mathrm{CH}=\mathrm{C}-\mathrm{C}-$. The chemical $\mathrm{CH}_{3}$

shift and intensity of the signal at $\delta 2.07$ clearly showed the presence of adjacent methylenes inserted between olefinic bonds. Thus, the partial structure is expressed as follows: aromatic ring $-\mathrm{CH}_{2}-\mathrm{CH}=\mathrm{C}-\mathrm{CH}_{2}-\mathrm{CH}_{2}-$ $\mathrm{CH}_{3}$

$\mathrm{C}=\mathrm{C}<. \quad$ On irradiation of a triplet at $\delta 4.50$ (1H), a methylene doublet at $\delta 2.39$ (adjacent to $\mathrm{C}=\mathrm{O}$ ) collapsed into a singlet and the unusually low chemical shift of a methine at $\delta 4.50$, in addition to the isolated coupling system, led to the following partial structure; $>\mathrm{C}=\mathrm{C}-\mathrm{C} \mathrm{C}-$ $\stackrel{+}{\mathrm{C}} \mathrm{H}_{3}$ $\mathrm{CH}_{2}-\mathrm{C}=\mathrm{O}$. On $\mathrm{NaBH}_{4}$ reduction of $\mathrm{I}$, dihydroxy derivative was formed, which no longer showed a carbonyl band in the IR absorption spectrum. Therefore, a remaining oxygen functionality should be etherial, since the presence of $\beta$-lactone or alcohol was excluded. The chemical shift of the gem-dimethyl at $\delta 1.20$ and 1.26 is consistent with $\beta$-position from both ketone and etherial oxygen. The evidences provided above established the structure of $\mathbf{I}$ as shown in Fig. 1. The MS data (Fig. 3) are in full agreement with the structure.

The IR spectral characteristics of II are very similar to those of I, but differ in lack of a carbonyl band at $1735 \mathrm{~cm}^{-1}$. In contrast, $\mathrm{O}-\mathrm{H}$ stretching vibration centered at $3300 \mathrm{~cm}^{-1}$ deepened and widened, and a new alcoholic stretching vibration appeared at $1090 \mathrm{~cm}^{-1}$ (secondary alcohol). When the NMR spectrum was compared with that of $\mathbf{I}$, a new triplet $(1 \mathrm{H})$ appeared at $\delta 3.95$ accompanying with a new alcoholic signal at $\delta 2.39$. The new triplet is clearly assignable to a methine with a hydroxyl.

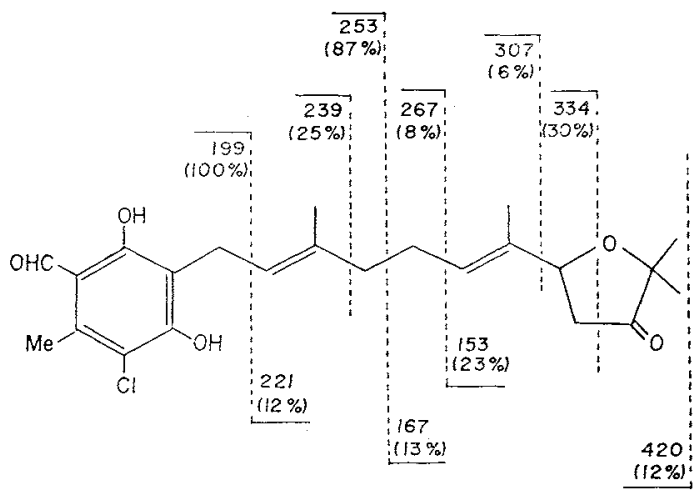

Table 2. NMR Spectrum of ascofuranone and

\begin{tabular}{l|c|c}
\hline \multirow{2}{*}{ Functionality } & \multicolumn{2}{|c}{ Chemical shift $(\delta)$ and shape* } \\
\cline { 2 - 3 } & Ascofuranone & Ascofuranol \\
\hline C-1-Aldehyde & $10.12 \mathrm{~s}$ & $10.11 \mathrm{~s}$ \\
C-2-Chelated OH & $12.68 \mathrm{~s}$ & $12.66 \mathrm{~s}$ \\
C-4-OH & $6.55 \mathrm{~s}$ & $6.98 \mathrm{~s}$ \\
C-6-Methyl & $2.50 \mathrm{~s}$ & $2.58 \mathrm{~s}$ \\
C-1' & $3.38 \mathrm{~d}$ & $3.37 \mathrm{~s}$ \\
C-2' & $5.21 \mathrm{t}$ & $5.18 \mathrm{t}$ \\
C-3'-Methyl & $1.63 \mathrm{~s}$ & $1.60 \mathrm{~s}$ \\
C-4',5' & $2.07 \mathrm{~s}$ & $2.06 \mathrm{~s}$ \\
C-6' & $5.50 \mathrm{~m}$ & $5.48 \mathrm{~m}$ \\
C-7'-Methyl & $1.79 \mathrm{~s}$ & $1.78 \mathrm{~s}$ \\
C-8 & $4.50 \mathrm{t}$ & $4.30 \mathrm{t}$ \\
C-9' & $2.39 \mathrm{~d}$ & $2.35 \mathrm{~d}$ \\
C-11'-Dimethyl & $1.20 \mathrm{~d}$ & $1.20 \mathrm{\&}$ \\
& $1.262 \mathrm{~s}$ & $1.262 \mathrm{~S}$ \\
C-10'-OH & & $2.38 \mathrm{~s}$ \\
C-10'- & & $3.95 \mathrm{t}$ \\
\hline
\end{tabular}

Solvent $\mathrm{CDCl}_{3}$, TMS as an internal standard

* The following abbreviations are used; s singlet, $\mathrm{d}$ doublet, $\mathrm{t}$ triplet, and $\mathrm{m}$ multiplet. ascofuranol
Fig. 3. Fragmentation pattern of ascofuranone.

Fig. 4. Fragmentation pattern of ascofuranol.

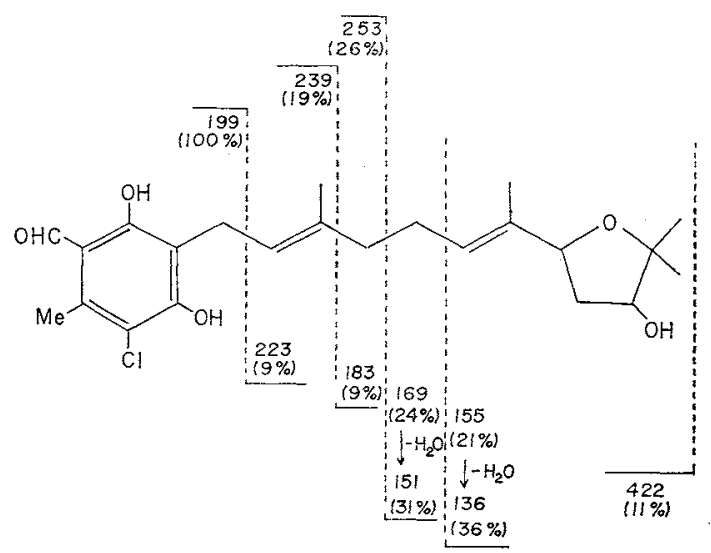


Instead of the doublet at $\delta 2.39$ of I a new multiplet appeared around $\delta 2.00$ and a methine proton at $\mathrm{C}-8^{\prime}$ shifted $0.2 \mathrm{ppm}$ higher than that of $\mathrm{I}$. The evidence provided above is consistent with the structure of $I I$ as shown in Fig. 1. In fact, I could be obtained from II by oxidation with chromium trioxidepyridine complex ${ }^{91}$, although the yield was as low as $20 \%$. The MS data of II afforded conclusive support. As shown in Fig. 4, all the fragment ions generated by fission between C-1'-C-2', $3^{\prime}-4^{\prime}, 5^{\prime}-6^{\prime}$ and $7^{\prime}-8^{\prime}$ were observed in the mass spectrum.

Since the isolation of ascochlorin in 1968, the class ascochlorin containing 5-chloroorcylaldehyde with 3-substituted terpenyl side chain have been isolated from many fungi such as Ascochyta viciae, Fusarium $^{\text {species }}{ }^{6)}$, Colletotrichum ${ }^{10,11)}$, Cylindrocladium ilicicola ${ }^{12)}$, Cylindrocladium species ${ }^{131}$ and Nectaria $^{14}$. However, I and II are the first in view of the novel sesquiterpenyl side chains of hydrofuranone structure. Stereochemistry of $\mathbf{I}$ and $\mathbf{I}$ remaining is now under way using X-ray method.

I is less toxic to mice and rats than III and effectively lowers serum lipid levels. The hypolipidemic property of $\mathbf{I}$ will be reported in a subsequent paper ${ }^{15 !}$.

\section{Experimental}

Melting points were taken on a micro hot-stage apparatus and are uncorrected. IR absorption spectra were determined as $\mathrm{KBr}$ disk, and UV spectra for solutions in methanol. NMR spectra were obtained at 60 and $100 \mathrm{MHz}$ in $\mathrm{CDCl}_{3}$ with tetramethylsilane as an internal standard. Molecular weights were taken from the parent peaks in the low resolution mass spectra. Merck silica gel $G$ was used in thin-layer chromatography.

Isolation of ascofuranone and ascofuranol: The Ascochyta viciae mutant strain No. 34 was grown in 30-liter jar fermentors for 7 days at $27^{\circ} \mathrm{C}$. The fermented broth was harvested and the chromatographic separation of $\mathbf{I}$ and $\mathbf{I I}$ was carried out as previously described ${ }^{3)}$. Ascofuranone; found $\mathrm{C}$ 65.24, $\mathrm{H} \mathrm{6.93,} \mathrm{Cl} 8.26 \%: \mathrm{M}^{+} 420 ; \mathrm{C}_{23} \mathrm{H}_{29} \mathrm{ClO}_{5}$ requires $\mathrm{C} \mathrm{65.62,} \mathrm{H} \mathrm{6.94,} \mathrm{Cl} 8.43 \% ; \mathrm{M}^{+} 420$. It is insoluble in water, slightly soluble in $n$-hexane, readily soluble in most organic solvents. It gave an intense purplebrown color with ferric chloride in ethanol. Ascofuranol; found $\mathrm{C} 65.31, \mathrm{H} 7.35, \mathrm{Cl} 8.42 \% ; \mathrm{M}^{+} 422$. The solubility was nearly the same as that of $\mathbf{I}$. Thin-layers of silica gel impregnated with I and II become green on sprying with sulfuric acid at $110^{\circ} \mathrm{C}$ for 5 minutes.

$\mathrm{NaBH}_{4}$ reduction of $\mathrm{I}: \quad \mathrm{I}(50 \mathrm{mg})$ was dissolved in $5 \mathrm{ml}$ methanol on cooling in an ice-bath. $\mathrm{NaBH}_{4}$ was added to the solution and the reaction mixture was stirred for 1 hour in an ice-bath. Then, excess $\mathrm{NaBH}_{4}$ was decomposed by adding $10 \%$ aqueous acetic acid. The mixture was concentrated in vacuo to syrup. Water $(10 \mathrm{ml})$ was added to the syrup and resultant emulsion was extracted with ethylacetate $(10 \mathrm{ml} \times 2)$. After dehydration of the combined extract with $\mathrm{Na}_{2} \mathrm{SO}_{4}$, the extract was concentrated in vacuo to dryness. The product was a colorless oil; found $\mathrm{C} 65.12, \mathrm{H} \mathrm{7.81,} \mathrm{Cl} 8.28 \%$; $\mathrm{C}_{2 s} \mathrm{H}_{33} \mathrm{ClO}_{5}$ requires $\mathrm{C} 65.02, \mathrm{H} \mathrm{7.78,} \mathrm{Cl} \mathrm{8.37 \%} ; \mathrm{M}^{+} 424, \mathrm{MW} 424.5, \nu_{\mathrm{max}}^{\mathrm{fl1m}} 3400,2970,2903,2850,1420$, $1228,1100 \mathrm{~cm}^{-1}$.

$\mathrm{CrO}_{3}$ oxidation of II: $\quad$ II $(423 \mathrm{mg})$ was dissolved in dry dichloromethane $(10 \mathrm{ml})$ and was added in one portion to the magnetic stirred oxidizing solution $(5 \%$ solution of chromic trioxide-pyridine complex in dry dichloromethane, $31 \mathrm{ml}$ ). After being stirred at room temperature for 15 minutes, the reaction mixture was filtered and the solvent was removed leaving the oily product $(407 \mathrm{mg})$ which was purified by the preparative thin-layer chromatography with $n$-hexane- acetone (4:1); yield of I was $83 \mathrm{mg}(19.7 \%)$.

Catalytic hydrogenation of I: A solution of I $(84 \mathrm{mg})$ in $10 \mathrm{ml}$ of cyclohexane - ethanol $(9: 1)$, was stirred overnight with $10 \mathrm{mg}$ of $10 \%$ Pd-charcoal under an atmosphere of $\mathrm{H}_{2}$, during which time approximately 2 moles of $\mathrm{H}_{2}$ was adsorbed. After filtration to remove the catalyst and evaporation of the solvent, the crude reduction product was subjected to preparative thin-layer chromatography on $30 \mathrm{~g}$ silica gel plate, was extracted with acetone and concentrated to give colorless oil $(52 \mathrm{mg})$. Found $\mathrm{C} 65.32, \mathrm{H} \mathrm{7.92,} \mathrm{Cl} 8.28 \% ; \mathrm{C}_{23} \mathrm{H}_{33} \mathrm{ClO}_{5}$ requires $\mathrm{C} 65.02, \mathrm{H} \mathrm{7.78,} \mathrm{Cl} 8.37 \%$. $\mathrm{M}^{+} 424, \mathrm{MW} 424.5$. 


\section{References}

1) Turner, W. B.: Fungal metabolites. Academic Press. pp. $232 \sim 235,1971$

2) Sasaki, H.; T. OKUTOMI, T. Hosokawa \& K. Ando: Ascofuranone, a new antibiotic from Ascochyta viciae. Tetrahedron Letters 1972: $2541 \sim 2544,1972$

3) Tamura, G.; S. Suzuki, A. Takatsuki, K. Ando \& K. Arima: Ascochlorin, a new antibiotic, found by paper-disc agar-diffusion method. J. Antibiotics 21: 539 544, 1968

4) Nawata, Y.; K. Ando, G. Tamura, K. Arima \& Y. Iitaka: The molecular structure of ascochlorin. J. Antibiotics 22: $511 \sim 512,1969$

5) Scotr, A. I.: Interpretation of the ultraviolet spectra of natural products. p. 113. Pergmon Press, London, 1964

6) Ellestad, G. A.; R. H. Evans, Jr. \& M. P. Kunstmann: Some new terpenoid metabolites from an unidentified Fusarium species. Tetrahedron 25: 1323 1334, 1969

7) Budzikiewicz, H.; C. Djerassi \& D. H. Willram.: Interpretation of mass spectra of organic compounds. p. 163. Holden-Day, Inc. San Francisco, 1964

8) Nakanishi, K.: Infrared absorption spectroscopy. Practical. p. 43. Holden-Day, San Francisco, 1962

9) Collins, J. C.; W. W. Hess \& F. J. Frank: Dipyridine-chromium. VI. Oxide oxidation of alcohols in dichloromethane. Tetrahedron Letters 1968: 3363 3366, 1968

10) SASAKI, H.; Y. NAWATA \& K. ANDO: Structure of ascochlorin and the analogs. Annual Meeting of Agr. Chem. Soc. Japan. p. 369, 1971

11) Kosuge, Y.; A. Suzuki, S. Hirota \& S. Tamura: Structure of colletochlorin from Colletotrichum nicotianae. Agr. Biol. Chem. 37: 455 456, 1973

12) Minato, H.; T. Katayama, S. Hayakawa \& K. Katagrri: Identification of ilicicolins with ascochlorin and LL-Z1272. J. Antibiotics 25: 315 316, 1972

13) Kato, A.; K. Ando, G. Tamura \& K. Aruma: Cylindrochlorin, a new antibiotic produced by Cylindrocladium. J. Antibiotics 23: $168 \sim 169,1970$

14) Aldridge, D. C.; A. Borrow, R. G. Foster, M. S. Large, H. Spencer \& W. B. Turner: Metabolites of Nectia coccinea. J. Chem. Soc., Perkin I, 1972: 2136 2141, 1972

15) Sawada, M.; T. Hosokawa, T. OKutomi \& K. ANDo: Hypolipidemic property of ascofuranone. J. Antibiotics 26: 681 686, 1973 